\title{
INLAND WATER BODIES MONITORING USING SATELLITE ALTIMETRY OVER INDIAN REGION
}

\author{
S. Chander, D. Ganguly, A.K. Dubey, P.K. Gupta, R.P. Singh and Prakash Chauhan
}

Biological and Planetary Sciences and Applications Group (BPSG), Space Applications Centre, Ahmedabad, India (schander, dganguly, a_dubey, pkgupta, rpsingh, prakash) @ sac.isro.gov.in

KEY WORDS: Satellite Altimetry, Waveform Retracking, Altimeter range corrections, GPS Kinematic mode

\begin{abstract}
:
Satellite altimetry for inland water applications has evolved from investigation of water height retrieval to monitoring since last two decades. Altimetry derived reservoir/ river levels can subsequently be used to deal with key inland water resources problems such as flood, rating curve generation for remote locations, reservoir operations, and calibration of river/lake models. In this work 29 inland water bodies were selected over Indian region to monitor from satellite altimetry. First cut selection of potential water bodies was based on availability of altimeter tracks and geographic locations. Then feasibility study was carried out to check the potential of availability of in-situ measurement and scope of GPS survey for final selection. An algorithm is proposed and tested for the waterlevel retrieval over the Ukai Reservoir which fulfil all the necessary requirements. The methodology is based on averaged high rate waveforms, modified retracker and range corrections. The results were then validated with the GPS survey and in-situ tide gauge dataset. SARAL derived water-level information for six different retrackers were compared with the in-situ tide-gauge dataset installed close to the Ukai Dam. Averaged high rate waveforms were analysed for better performance, i.e. single 40Hz, and multiple 40-Hz. A field trip was conducted on $17^{\text {th }}$ January 2014, same day on the SARAL pass, using two Dual frequency GPS instruments. New improved retracker work best with overall RMSE within the range of $8 \mathrm{~cm}$. The results supports that AltiKa dataset can be utilized for more accurate water level information over inland water bodies.
\end{abstract}

\section{INTRODUCTION}

Inland waters such as lakes, rivers, wetlands, and floodplains have a profound influence on human culture and society. The majority of the global population lives along the river system primarily due to easy access to water resources for agriculture, drinking, domestic and industrial uses, conveyance of goods, and transportation (Berry et al., 2005). The amount and availability of terrestrial water have crucial impact on human life, it also play a great role in global hydrological cycle. Worldwide, the number of operational discharge monitoring stations has been decreasing continuously since the 1970's (Fekete and Vorosmarty 2007).

Measurements and the temporal variations in water levels of rivers, lakes and reservoirs are necessary due to various problems such as (a) many developing countries have insufficient networks of hydrological gauging stations especially in the remote and high flow locations (b) Hydrological models, which are widely used by water managers as a decision support tool for both real-time and long-term applications such as optimal management of reservoir releases, water allocation in drought conditions etc., face problem of initialization and calibration (c) flood forecasting systems are developed to predict flooding events based on the real time observations of water levels. Since, flooding after rainstorms or typhoons can seriously damage property, routine monitoring of river surface changes is critical for disaster risk management as well as for hydrological and climatological research. Knowledge and prediction of the quantities of water flowing in rivers is of great importance in order to improve water allocation efficiency, reservoir and hydropower operation or in order to mitigate floods and droughts (Calmant et al., 2008).
To understand the hydrological budget over the continental surface, inland water bodies must be monitored regularly. Monitoring inland waters plays a major role in investigating the hydrological processes and management of water resources. Our ability to monitor rivers and associated floodplain water levels can greatly help in management of hydrological disasters, and calibrating and validating hydrological models. The traditional monitoring of river gauges is limited to few locations over a river basin. But, non-availability of in-situ measurements at desired locations imposes serious constraints on basin scale hydrology study of large rivers like the Brahmaputra River. Besides this, in-situ discharge measurement of a large wide river like the Brahmaputra is too much expensive and time consuming. The total amount of fresh water flowing in rivers and to the ocean is also an important unknown of global circulation models which are used to drive weather and climate models (Alsdorf et al., 2007). Remote sensing from satellite platform has the potential to monitor inland water bodies continuously and consistently over the long period of time and to support subsequent hydrologic-hydraulic modeling for planning and management of water resources at regional scales.

\subsection{Radar Altimetry}

Satellite radar altimeters were primarily designed to study variations in the surface elevation of the oceans (Fu and Cazenave 2001). Innovative use of the data, however, has additionally enabled studies of the variations in surface water level of the inland water bodies (Birkett and Mason 1995). The main advantages include day/night and all weather operation with no loss of data because of cloud coverage. With continuous operation across all surfaces, the instrument behaves like a string of pseudo-gauges, sampling the elevation at discrete intervals along a narrow satellite ground track. The

Corresponding author schander@sac.isro.gov.in 
presence of vegetation or canopy cover is not a hindrance to this nadir-viewing instrument, the inundated surfaces being so bright at microwave frequencies that vegetation only interferes during periods of extremely low water level. The instruments can thus observe monthly, seasonal, and inter-annual variations over the lifetime of the mission, and unlike many gauge networks that operate using a local reference frame, all altimetric height measurements are given with respect to one reference datum to form a globally consistent, uniform data set. After several decades of validated research, the altimetry data sets are mature and generally freely available via ftp.

A radar altimeter principally works by transmitting a short microwave pulse in the nadir direction, and then examining the echo reflected by the surface. The return radar power received by the altimeter is recorded through time, producing an altimetric waveform. By analysing amplitude and waveform of the return signal, various characteristics of the surface such as backscatter coefficient, surface roughness, wave height and wind speed over oceans, etc. can be quantified (Chelton et al., 2001). A detailed discussion of the derivation of altimetric heights and their associated errors can be found in $\mathrm{Fu}$ and Cazenave (2001). With respect to lake/reservoir monitoring, there are several limitations to utilizing radar altimetry. The altimetric satellites are placed in a fixed repeat-cycle orbit with instruments that only have nadir-pointing ability. These result in specific ground track locations that restrict viewing to a certain percentage of the world's lakes and reservoirs. A tradeoff between the temporal and spatial sampling is also in play and can impose further restrictions on target numbers. Many altimetric missions also have ocean science objectives with instrument designs not optimized for studies in rapidly changing or complex (multiple target) terrain. In such cases, surface elevation data over inland water may be degraded or non-retrievable. In addition, a number of factors place limitations on lake size.

\begin{tabular}{|c|c|c|c|c|c|}
\hline Mission & $\begin{array}{c}\text { Band } \\
(\mathrm{GHz})\end{array}$ & $\begin{array}{c}\text { Heigh } \\
\mathrm{t} \\
(\mathrm{km})\end{array}$ & $\begin{array}{c}\text { Repeat } \\
\text { ability } \\
\text { (days) }\end{array}$ & $\begin{array}{c}\text { Trac } \\
\mathrm{k} \\
\text { spaci } \\
\text { ng at } \\
\text { equat } \\
\text { or } \\
(\mathrm{km})\end{array}$ & $\begin{array}{c}\text { PRF } \\
(\mathrm{Hz})\end{array}$ \\
\hline SARAL & $\begin{array}{c}\mathrm{Ka} \\
(36.5)\end{array}$ & 800 & 35 & 80 & 4000 \\
\hline JASON-2 & $\begin{array}{c}\mathrm{Ku} \\
(13.6) \\
\mathrm{C} \\
(5.3)\end{array}$ & 1336 & 9.9156 & 320 & 1800 \\
& & & & 300 \\
\hline
\end{tabular}

Table 1. Technical Specifications of current altimetry missions

Jason-2 and Envisat satellites have been acquiring radar altimeter data for last 10 years. Current altimetric satellites cross over a selection of the world's largest lakes and reservoirs, measuring variations in the lake level with a repeat frequency ranging from 10 to 35 days is shown in Table 1 . While the NASA/CNES missions (Jason-1/2) have the better temporal resolution, ideal for weekly updates of lake products, the ESA missions (Envisat) offer a far greater quantity of potential targets. Literature on water level estimation over rivers have shown the capability of satellite altimetry to produce water level time series such as Ob river (Kourae et al., 2004), different sites along the Amazon river (Zakharova et al.,
2006), Ganga and Brahmaputra river (Papa et al., 2010) using nearby gauging stations to calibrate the water level.

With the successful launch of SARAL by ISRO this time series will be prolonged into the future. Although higher frequency will have higher water vapor effect and will be highly sensitive to rain, but this can be exactly estimated with the help of onboard radiometer. Higher frequency provides less ionosphere delay and better vertical resolution. SARAL offers larger bandwidth of $500 \mathrm{MHz}$ compared to existing limit of bandwidth of $320 \mathrm{MHz}$. Higher bandwidth result in smaller pulse width, i.e. $2 \mathrm{~ns}$ in the case of SARAL compared to $3.125 \mathrm{~ns}$ in the case of Envisat altimeter. At the orbit height of $800 \mathrm{~km}$ Envisat yields annuls area $2.11 \mathrm{~km}$ while for SARAL, the effective foot print area will be $1.3 \mathrm{~km}$ for the similar flat sea surface. SARAL has higher pulse repetition frequency (PRF) of $4 \mathrm{kHz}$ compared to Envisat PRF $(2 \mathrm{kHz})$. At this height generally satellite travels with a speed of nearly $7 \mathrm{~km} / \mathrm{sec}$. SARAL onboard computation and higher PRF allows to send $40 \mathrm{~Hz}$ information as compared to $20 \mathrm{~Hz}$ in case of Envisat. That means SARAL is providing information every $175 \mathrm{~m}$ along the satellite track compared to $350 \mathrm{~m}$ along the track in the case of Envisat. These comparison shows SARAL altimeter can be used for extracting more information over smaller water bodies like lakes and rivers.

For each mission, the data sets are offered to users in several formats including Fast Delivery (generated within a few hours after satellite overpass), Intermediate Geophysical Data Records (IGDR, available a few days after satellite overpass) and Geophysical Data Records (GDR, generally available 4-6 weeks after overpass). Notably, the lake-level accuracy depends upon the knowledge of the satellite orbit that is deduced via Global Positioning System (GPS), doppler orbit determination, and radio-positioning integrated on satellite (DORIS), and satellite laser ranging (SLR) methods. Fast delivery data may contain mean global orbit errors of $\sim 30-40 \mathrm{~cm}$; IGDR errors are $\sim 5-10 \mathrm{~cm}$ and GDR errors $\sim 2-3 \mathrm{~cm}$. Striking a balance between height accuracy and operational requirements, the IGDR data was selected for near-real-time observations and the archive product was constructed using the GDR product (SARAL/AltiKa product handbook).

\section{OBJECTIVES \& STUDY AREA}

Observing the river/lake/reservoir water levels via the innovative use of satellite radar altimetry combined with satellite imagery does offer the potential to monitor variations in water yield productions. There is need for archival information that could reveal the general status of the major water bodies, and the availability of near-real-time data that could quickly assess drought or high water-level conditions. The major objectives of this work are:

(i) To monitor water levels of major rivers, lakes and reservoirs of India.

(ii) To integrate retrieved water levels with hydrological and hydrodynamic models for the generation of various hydrological products such as seasonal water yield productions in the major river/reservoir catchments, discharge pattern, rating curves etc.

(iii) Development of SARAL-Altika web portal for uploading near real time hydrological products.

Total 23 inland water bodies were selected for observing the water level fluctuations using satellite altimetry, i.e. 5 rivers, 9 
lakes and 9 reservoirs. These inland water bodies were selected such that there is at least 1 altimeter pass over them. GandhiSagar that is situated in the Madhya Pradesh, is having area nearly $720 \mathrm{~km}^{2}$, and satellite passes $18 \mathrm{~km}$ along the track. Over Chilka lagoon SARAL track number 137 passes nearly $29 \mathrm{~km}$ along the track, while Jason-2 track number 192 passes $24 \mathrm{~km}$ along the track. Over Brahmaputra River total 14 intersections points and for Ganga River 11 intersection points between altimeter track and river were selected finally for further analysis. Detailed information about the location, satellite track number, along track distance and approximate area is given in the tables 3-4 (Appendix) respectively for rivers, lakes and reservoirs. Figure 1 presents selected water bodies locations over India.

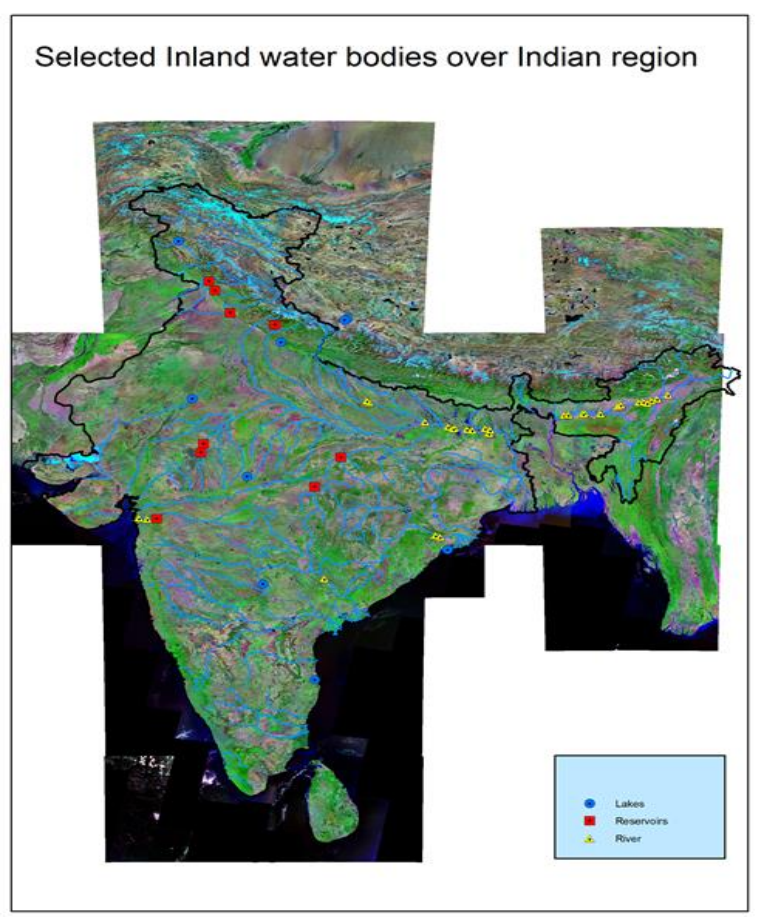

Figure 1. Water level retrieval locations for River (Yellow) and Reservoir (Red)/Lake (Blue) over India including Himalayan region.

\section{METHODOLOGY}

Over the inland water bodies altimeter gets very complex and multi-peaked waveforms due to complex terrain and rapidly varying slopes. Given the fact that the radar altimeter footprint varies in terms of few squares of kilometer, presence of vegetation and sand bar/islands in a braided river system distort the return power of the waveform. The return power from the water surface remains higher as compared to the other surface features present within the footprint of the altimeter due to its dielectric property and surface characteristics. A flow chart explaining the methodology adopted to generate the reliable water level information is shown in figure 2. In order to minimize potential contamination of SARAL signal by land reflections and at the same time to retain a sufficiently large number of altimeter measurements on the water surface. We have used Landsat- 7 and Landsat- 8 panchromatic images of 15 m pixel resolution, downloaded from the Earth Explorer portal, to select the satellite track and river intersections during the lean flow.

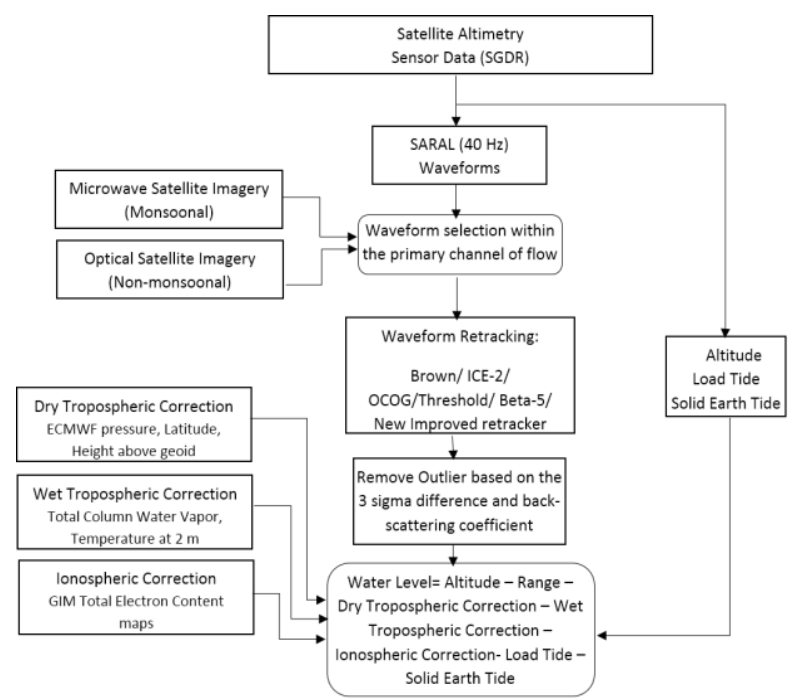

Figure 2. Flow-chart showing the methodology for the retrieval of water level over Inland Water bodies.

Geophysical range correction algorithms were modified for inland water bodies. Dry tropospheric correction that considers sea level pressure was modified based on the altitude of the measurement. For this purpose the height above the EGM2008 geoid was computed by subtracting the EGM2008 geoid height above a reference ellipsoid from the water level height above the same ellipsoid. The DTC has strong height dependence and since satellite altimetry is primarily designed for ocean applications, for which no such dependence exists, some altimeter products fail to provide the DTC appropriate for inland water studies (Fernandes et al., 2014). Reanalysis pressure fields were also tested for observing the uncertainty in the pressure measurement itself, by using following pressure fields, i.e. NCEP, ECMWF and ERA. But we are aiming to provide water level information within near real time that requires data availability within 2-3 days. So further in this work we have used operational ECMWF analysis derived surface pressure. Total column water vapour and temperature was used to estimate the wet tropospheric correction. GIM maps were used for extracting the TEC information that was converted to ionospheric delay. For smaller inland water bodies earth tide is applied, but elastic-ocean and ocean-loading tides are only applicable larger water bodies $\left(\sim 1000 \mathrm{~km}^{2}\right)$. The inverse barometric correction is not applied because the lakes/reservoirs are closed systems. The sea state bias (SSB) correction is also not applied because wind effects tend to be averaged out along-track.

\section{RESULTS}

Ukai dam/reservoir is situated in the District Tapi, South Gujarat, India. It is constructed across the Tapi River. This reservoir is important for irrigation, flood protection, hydroelectricity generation. This is the one of the biggest reservoir of Gujarat having water spread of 52,000 hectare. It has catchment area of $62,255 \mathrm{~km}^{2}$, and there is one river (Tapi) through which the reservoir water flows out. As shown in Figure 3, there is one pass of SARAL/Altika across the lake, pass 825 . Several points of pass 825 are located in the middle of the reservoir. As the waveforms in the middle of the reservoir follow the Brown model without the effect of land topography, this can give a more accurate surface height information. Hourly records of the in-situ gauge, nearly $5 \mathrm{~km}$ away from the SARAL altimeter ground track (Figure 3), was provided by the 
Flood Cell, Ukai division, Tapi, Gujarat, covering the time span January 1972-January 2014.

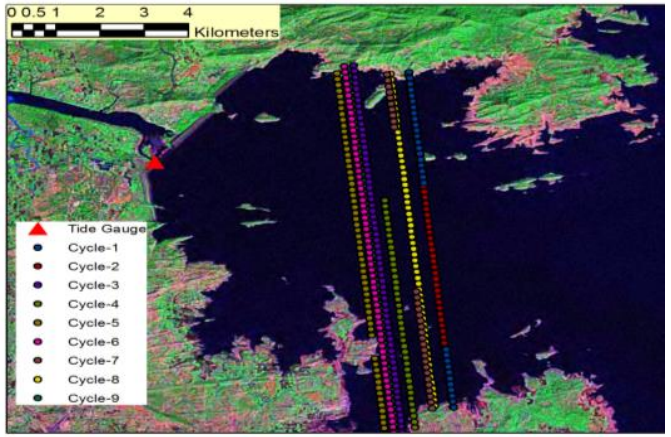

Figure 3. Landsat-8 image of Ukai reservoir is shown along with SARAL pass number 825 , Red dot shows the Tide gauge location

The outliers were removed by the boundary limits set according to each water body. As shown in the figure 3, different color shows the altimeter track for first nine cycles over the reservoir. Red color spot shows the location of tide gauge installed the Dam authority. Along the track satellite covers nearly $10 \mathrm{~km}$ width of the reservoir. Total 498 waveforms were acquired over the Ukai reservoir during the study period. Waveforms were selected based on the backscattering information and the geographical location mapped with the help of microwave imagery (Landsat- 8 image). During cycle 1 we observe the loss of altimeter track close to the middle of the Dam. We planned a GPS survey during cycle 4 , and visited Ukai Dam on $26^{\text {th }}$ July 2013. But could not conduct the experiment in the vicinity of the Dam due to bad weather. Satellite also faces the problem and could not acquire data during this pass. During this visit, we have placed one GPS in static mode closed to the tide gauge installed by the Dam authority and cross calibrated both the instruments. A field trip was conducted on $17^{\text {th }}$ January 2014 for acquiring the water level information over the reservoir using two Dual frequency GPS (DGPS). We will discuss this later in the paper. Firstly we have classified the waveforms based on the shape. Waveforms from centre of the reservoir was typical high powered spikes which is similar to signal returns over oceans. As we move towards the bank, waveforms become broader and noisier.

Out of total 498 waveforms, 150 were having brown like shape, 51 were having Brown-like shape with noisy trailing edge, 56 were specular shape, 69 were rectangular shape and 114 were having multi-peak. Remaining 58 waveforms which does not fall under any category and mostly having only noise level power were eliminated in the further processing. The maximum proportion of the waveforms are allocated by the flat patch waveforms brown and multi peak. This illustrates again the fact that, the shape of the waveforms are totally different from one cycle (season) to another, even on the same geographic location. In fact, various shape of waveforms can occur due to the effect of topography, season, vegetation and water availability.

These waveforms were than retracked using waveform retracking algorithms, including the offset center of gravity (OCOG), ICE-2, Beta-5, Brown, the threshold. ICE-2 retracking algorithm is based on the Brown model (Brown, 1977), fitting the altimetric waveform with an error function (erf) for the leading edge and an exponential decrease for the trailing edge slope and deduce the waveform integration, thus providing the parameter estimates (Legresy et al., 2005). Beta-5 retracker was first proposed by (Martin et al., 1983). It is a five parameter functional model designed to derive geophysical parameters for Brown like waveforms obtained over ocean and large water bodies by trying to fit the acquired waveform to the model curve. The OCOG retracker (Wingham et al., 1986) was originally developed based on an empirical method to retrieve ERS-1/2 echoes from ice surfaces by calculating the amplitude and the width of the waveform to accurately determine the leading edge position. The OCOG retracker is normally used for rectangular type waveforms where no model can be fitted. The threshold retracker (Davis, 1997) was primarily designed to retrieve altimetric ice elevation changes using a statistical algorithm. It determines the leading edge by locating the first waveform sample that exceeds a specific threshold level, generally set to $10 \%, 20 \%$, or $50 \%$. David (1997) suggested that a $50 \%$ threshold level could be used for surface-scattering.

The new improved retracker consist of firstly identify the different sub waveforms within a multipeak waveform and then identify the subwaveform corresponding to the target at nadir. This selection was based on the power difference between consecutive gates and power difference between every alternate gates. The subwaveform is then retracked using the 50\% threshold to find the correct retracked range and water height. Subwaveform based retracking technique like the improved threshold exist in the literature but it requires some reference data of water level height to identify the appropriate subwaveform and determine the correct range (Hwang et al., 2006), so it cannot be used in cases where no reference data is available. The basic assumption in this new retracker is that the first leading edge is coming from the surface closest to the satellite and for flat surfaces it is from the nadir. This methodology works fine for surfaces which are nearly flat with very smaller slope over the footprint area, i.e. reservoirs and lakes where the surface slope is almost zero for most parts of the water body except near the boundaries $(\sim 1 \mathrm{~km}$ from boundary). Table 2 shows the ability of the retracker to show consistent result all over the reservoir for different shapes of the waveform.

\begin{tabular}{|c|c|c|c|c|c|c|}
\hline Cycle & $\begin{array}{c}\text { Brown } \\
(\mathrm{m})\end{array}$ & $\begin{array}{c}\text { ICE- } \\
2 \\
(\mathrm{~m})\end{array}$ & $\begin{array}{c}\text { OCOG } \\
(\mathrm{m})\end{array}$ & $\begin{array}{c}\text { Threshold } \\
(\mathrm{m})\end{array}$ & $\begin{array}{c}\text { Beta- } \\
5(\mathrm{~m})\end{array}$ & $\begin{array}{c}\text { New } \\
\text { Improved } \\
(\mathrm{m})\end{array}$ \\
\hline 1 & 0.25 & 0.36 & 0.18 & 0.45 & 0.29 & 0.51 \\
\hline 2 & 0.12 & 0.14 & 0.08 & 0.16 & 0.26 & 0.13 \\
\hline 3 & 0.15 & 0.16 & 0.16 & 1.11 & 0.16 & 0.18 \\
\hline 4 & 5.35 & 2.96 & 0.96 & 3.15 & 3.99 & 3.68 \\
\hline 5 & 0.33 & 0.41 & 0.33 & 6.61 & 0.45 & 0.32 \\
\hline 6 & 5.18 & 0.83 & 0.13 & 1.76 & 0.23 & 0.17 \\
\hline 7 & 0.06 & 0.16 & 0.05 & 0.52 & 0.08 & 0.01 \\
\hline 8 & 0.49 & 1.15 & 0.25 & 1.03 & 0.57 & 0.05 \\
\hline 9 & 3.79 & 2.38 & 0.32 & 3.70 & 3.17 & 0.22 \\
\hline
\end{tabular}

Table 2. Shows the standard deviation of height observed by different retrackers within Ukai Dam

OCOG retracker shows the best consistency, for all type of waveform. As this is purely statistical retracker which does not depend on the physical properties of the surface, was found to be more sensitive to the leading edge of the waveform. In the brown retracker large variation was found especially for the multi-peak waveforms. New improved retracker works fine overall the study period, even better in comparison to other 
retrackers after Cycle 7. Some inclination manoeuvres have been applied to reach the good orbit. Last manoeuvre was applied during cycle 7 ( $28^{\text {th }}$ October 2013$)$ to reach the historical orbit of Envisat. Since this time the satellite gets a good repetitively. An additional selection criteria was applied based on the 3 sigma deviation from the mean value and backscatter coefficient. This is especially useful for locations where the width of inland water body varies greatly between wet and dry seasons as seasonal variations in river width and sand bars in the mid of the reservoir.

Figure 4 shows the variability of atmospheric range correction parameters over the Ukai reservoir. During June-September (cycle 3-6) we have observed larger wet tropospheric correction of the order of $40 \mathrm{~cm}$, maximum value was observed $45 \mathrm{~cm}$ in Cycle 4. The Dry tropospheric correction follows the trend with larger values during Cycle 7- Cycle 10, with smaller values in the monsoon months. Due to higher frequency the effect of ionospheric correction was very less as expected of the order of 2-6 $\mathrm{mm}$.
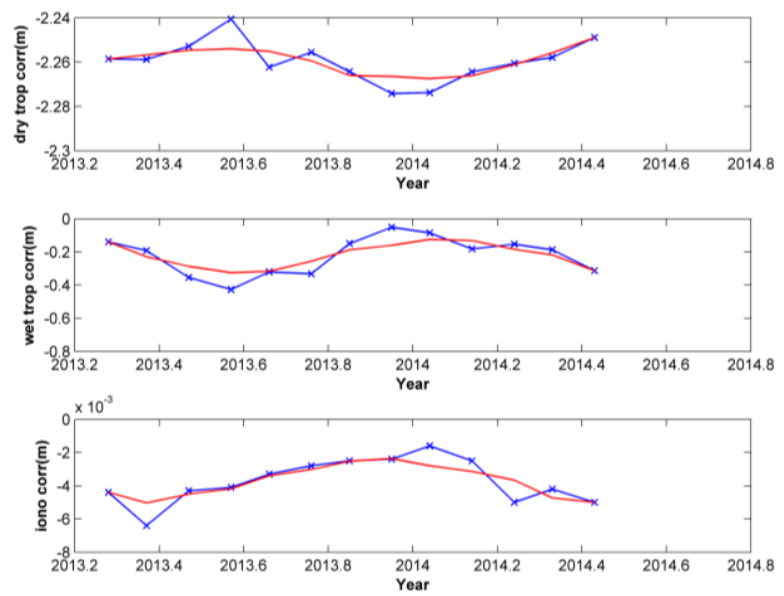

Figure 4. Variability of atmospheric correction parameters over the Ukai reservoir during March 2013 to April 2014

The root mean square error, RMSE, and coefficient of determination R2, were considered as reference measures to estimate the discrepancy between the satellite observations and in-situ series. Cycle 4 results have been removed from final results because waveforms were corrupted due to rain. All heights are measured with respect to mean sea level. The point that lies closest to the tide gauge location and lies in the center of the reservoir, was selected as the virtual station for that cycle after carefully examine the backscatter. Figure 5 shows the comparison between water level heights at virtual station as retrieved by SARAL altimeter after applying the dedicated inland water body range corrections, for six different retrackers. Brown retracker could not retrack the multi-peak waveform accurately and results in lowest R2 of the order of 0.25 only. ICE-2 and Beta-5 were slightly better with R 2 close to 0.9 , but the RMSE was of the order of $1.5 \mathrm{~m}$. For threshold retracker R2 was 0.93 and RMSE was $1.13 \mathrm{~m}$ that suggests it was not able to select the exact leading edge in the waveform. OCOG retracker works best within the existing retrackers with RMSE within the range of $10 \mathrm{~cm}$. New improved retracker further improves the accuracy with RMSE close to $8 \mathrm{~cm}$. But if we select the wrong virtual station the result may change drastically, so the coherence length of the altimeter was further investigated using OCOG and new modified retracker.
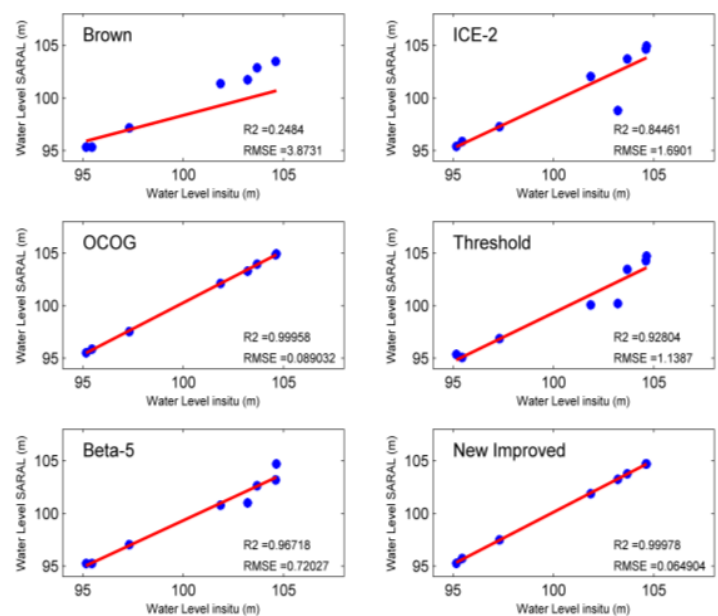

Figure 5. Comparison between Water level heights obtained with different retrackers using SARAL altimeter v/s in-situ observations over the Ukai reservoir during period March 2013January 2014

Generally waveforms are averaged out to reduce the noise of individual waveforms. In oceanographic applications the altimeter data further averaged over time period of about $1 \mathrm{sec}$ (Chelton et al., 2001). New methodology based on combinations of averaged high rate waveforms were analysed for better performance, i.e. single $40 \mathrm{~Hz}$, many $40-\mathrm{Hz}$. Figure 6 shows the statistical results for $(a, b)$ three waveforms retracked then average, $(c, d)$ five waveforms retracked then average, $(e, f)$ three waveforms averaged then retrack, and (g,h) five waveforms averaged then retrack respectively for OCOG and New improve retracker.
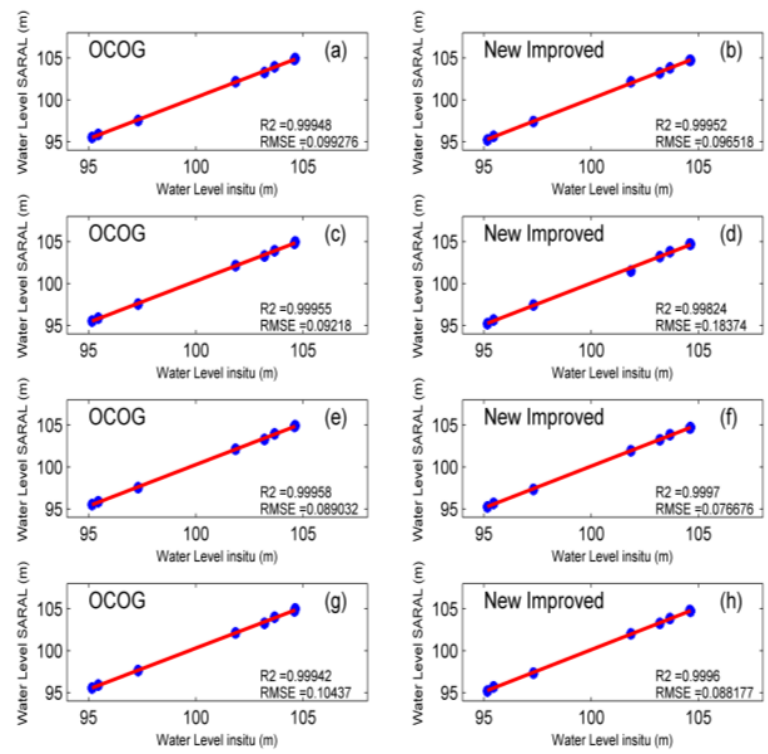

Figure 6. Comparison between Water level heights with OCOG retracker and new improved retracker v/s in-situ observations for different average combinations over the Ukai reservoir during period March 2013- January 2014

As can be seen from the above figure, if we average three closest point after retracking the results still comes better with RMSE of the order of $9 \mathrm{~cm}$. That explains the smaller coherence length of the SARAL altimeter of the order of $500 \mathrm{~m}$ along the track. But if firstly we average the waveform and then retrack, the water level matches very well with in-situ for our 
newly developed retracker with RMSE around $8 \mathrm{~cm}$. During GPS survey, first GPS was mounted as static mode close to the Dam authority measurement system for reference and second GPS was mounted over the boat for navigation close to the SARAL altimeter track in Kinematic mode. As it is clear from figure 3 , the altimeter ground track may move within $1 \mathrm{~km}$ from the reference track, we have taken measurement in the proximity of the master track within $1 \mathrm{~km}$ both the sides. After data processing 30 data points which were lying close to actual pass were selected for final processing. The mean height estimated by GPS was 103.14 meter, with standard deviation of $3.4 \mathrm{~cm}$. While the in-situ tide gauge measurement was 103.20 meter, and new improved retracker estimate the height 103.18 meter.

\section{CONCLUSIONS}

In this paper we have reported the proportions of different waveforms over Ukai reservoir obtained from SARAL radar altimeter. Using knowledge for the Microwave imagery and back scatter information from the altimetry, 29 water bodies were finally selected for the monitoring through satellite altimetry. The basis of selection was the availability of altimeter track, along track distance of the track, minimum area of the water body, and satellite repeatability over the same geographical location. An algorithm was proposed for determining water level in inland water bodies. Dedicated inland water bodies atmospheric range correction were applied during retrieving the water level height. Averaged high rate waveforms were analysed for better performance, i.e. single $40 \mathrm{~Hz}$, and multiple $40-\mathrm{Hz}$ combinations. Finally we conclude that if we mean closest three waveforms before retracking, retrack with the new improved retracker and apply the dedicated inland water body geophysical range corrections, the final water level can be estimated within accuracy of less than decimetre $(\sim 8 \mathrm{~cm})$. This investigative water level information case studies can be integrated with the hydrological models and other remote sensing techniques to generate other hydrological products. The results supports that AltiKa dataset can be utilized for more accurate water level information over inland water bodies.

\section{ACKNOWLEDGEMENTS}

The authors are thankful to Shri A. S. Kirankumar, Director, Space Applications Centre, and Dr. P.K. Pal, Dy. Director, Earth Ocean Atmosphere, Planetary Sciences and Applications Area for their keen interest in this study. Authors are also thankful to Shri. S.A. Vahiya, Executive Engineer, and Shri R. R. Singh, Engineer, Flood Cell, Ukai division, Tapi, Gujarat for providing the in-situ data over the reservoir.

\section{REFERENCES}

Alsdorf, D. E., Rodriguez E., and Lettenmaier D. P., 2007. Measuring surface water from space. Reviews of Geophysics, 45, RG2002, doi: 10.1029/2006RG000197.

Berry, P. A. M., Garlick, J. D., Freeman, J. A., \& Mathers, E. L., 2005. Global inland water monitoring from multi-mission altimetry. Geophysical Research Letters, 32, L16401, doi:10.1029/2005GL022814.

Birkett C. M. and Mason I. M., 1995. A new global lakes database for a remote sensing programme studying climatically sensitive large lakes. J Great Lakes Res 21(3), pp. 307-318.
Brown, G.S., 1977. The average impulse response of a rough surface and its applications, IEEE Transactions on Antennas and Propagation, AP-25 (1), pp. 67-74.

Calmant, S., Seyler, F., and Cretaux, J. F., 2008. Monitoring Continental Surface Waters by Satellite Altimetry, Survey in Geophysics, special issue on 'Hydrology from Space', 29, pp. 247-269.

Chelton, D. B., Ries, J. C., Haines, B. J., Fu, L. L. and Callahan, P. S., 2001. Satellite Altimetry, In Satellite Altimetry and the Earth Sciences: A Handbook of Techniques and Applications, Fu, L. L. and Cazenave A. (Eds.), Academic Press, San Diego CA, pp. 1-131.

Davis C.H., 1997. A robust threshold retracking algorithm for measuring ice-sheet surface elevation change from satellite radar altimeter. IEEE Transactions on Geoscience and Remote Sensing, 35(4), pp. 974-979.

Fekete, B. M. and Vorosmarty, C. J., 2007. The current status of global river discharge monitoring and potential new technologies complementing traditional discharge measurements. IAHS publ. 309.

Fernandes, M.J., Lázaro, C., Nunes A.L., and Scharroo R., 2014, Atmospheric Corrections for Altimetry Studies over Inland Water, Remote Sens., 6, pp. 4952-4997.

Hwang C., Guo J.Y., Deng X.L., 2006. Coastal gravity anomalies from retracked geosat/GM altimetry: improvement, limitation and the role of airborne gravity data. J Geodesy 804, pp. 204-216.

Legresy Benoit, Fabrice Papa, Frederique Remy, Gaetan Vinay, Mathias van den Bosch, Ouan-Zan Zanife, 2005. ENVISAT radar altimeter measurements over continental surfaces and ice caps using the ICE-2 retracking algorithm. Remote Sensing of Environment 95, pp.150-163.

Martin, T. V., H. J. Zwally, A. C. Brenner, and R. A. Bindschadler, 1983. Analysis and retracking of continental ice sheet radar altimeter waveforms, J. Geophys. Res., 88(C3), pp. $1608-1616$.

Papa, F., Durand, F., Rossow, W. B., Rahman, A., \& Bala, S. K., 2010. Satellite altimeter-derived monthly discharge of the Ganga-Brahmaputra River and its seasonal to interannual variations from 1993 to 2008. J. Geophys. Res., 115, C12013, doi:10.1029/2009JC006075.

SARAL/AltiKa Products Handbook, CNES/EUMETSAT/ISRO Issue 2, Rev. 2, June 18, 2013.

Wingham D.J., C.G. Rapley and H. Griffiths, 1986. New techniques in satellite tracking system. Proceedings of IGARSS'86 symposium, Zurich, pp. 1339-1344.

Zakharova, E. A., Kouraev, A. V., Cazenave, A., \& Seyler, F., 2006. Amazon River discharge estimated from TOPEX/Poseidon altimetry. Comptes Rendus Geoscience, 338 (3), pp. 188-196. 


\section{APPENDIX}

\begin{tabular}{|c|c|c|c|c|}
\hline Reservoir & $\begin{array}{c}\text { Location } \\
\text { (Lon./Lat. } \\
\text {, degree) }\end{array}$ & $\begin{array}{c}\text { Area } \\
\text { (sq. km) }\end{array}$ & $\begin{array}{c}\text { Satellite } \\
\text { Track }\end{array}$ & $\begin{array}{l}\text { Width } \\
\text { along the } \\
\text { pass } \\
\text { (Approx.) }\end{array}$ \\
\hline $\begin{array}{c}\text { Maharana } \\
\text { Pratap } \\
\text { Sagar }\end{array}$ & $\begin{array}{c}76.01 \mathrm{E}, \\
32.02 \mathrm{~N} \\
\text { Himachal } \\
\text { Pradesh }\end{array}$ & 240 & $\begin{array}{c}\text { SARAL - } \\
926\end{array}$ & $17 \mathrm{~km}$ \\
\hline $\begin{array}{l}\text { Govind } \\
\text { Sagar }\end{array}$ & $\begin{array}{l}76.62 \mathrm{E} \\
30.97 \mathrm{~N} \\
\text { Punjab } \\
\end{array}$ & 168 & $\begin{array}{c}\text { SARAL - } \\
382\end{array}$ & $2 \mathrm{~km}$ \\
\hline $\begin{array}{l}\text { Gandhi } \\
\text { Sagar }\end{array}$ & $\begin{array}{l}75.43 \mathrm{E}, \\
24.36 \mathrm{~N} \\
\text { Madhya } \\
\text { Pradesh }\end{array}$ & 723 & $\begin{array}{c}\text { SARAL- } \\
840,653 \\
\text { JASON2 } \\
-105\end{array}$ & $\begin{array}{c}18.5 \mathrm{~km} \\
0.5 \mathrm{~km}\end{array}$ \\
\hline $\begin{array}{l}\text { New } \\
\text { Tehri } \\
\text { Dam }\end{array}$ & $\begin{array}{c}78.45 \mathrm{E}, \\
30.41 \mathrm{~N} \\
\text { Uttrakhan } \\
\text { d }\end{array}$ & 52 & $\begin{array}{c}\text { SARAL - } \\
395 \\
754\end{array}$ & $2.5 \mathrm{~km}$ \\
\hline $\begin{array}{c}\text { Bargi } \\
\text { Dam } \\
\text { Reservoir }\end{array}$ & $\begin{array}{l}\text { 80.07E, } \\
22.75 \mathrm{~N} \\
\text { Madhya } \\
\text { Pradesh }\end{array}$ & 268 & $\begin{array}{c}\text { SARAL - } \\
38\end{array}$ & $2 \mathrm{~km}$ \\
\hline $\begin{array}{c}\text { Ban Sagar } \\
\text { Dam/ } \\
\text { Reservoir }\end{array}$ & $\begin{array}{l}81.13 \mathrm{E}, \\
24.13 \mathrm{~N} \\
\text { Madhya } \\
\text { Pradesh }\end{array}$ & 587 & $\begin{array}{c}\text { SARAL } \\
-496, \\
853, \\
\text { JASON2 } \\
-3\end{array}$ & $1.4 \mathrm{~km}$ \\
\hline $\begin{array}{c}\text { Ranjit } \\
\text { Sagar } \\
\text { Dam } \\
\end{array}$ & $\begin{array}{c}32.46 \mathrm{~N}, \\
75.76 \mathrm{E} \\
\text { Haryana }\end{array}$ & 40 & $\begin{array}{c}\text { SARAL - } \\
23\end{array}$ & $4.3 \mathrm{~km}$ \\
\hline $\begin{array}{l}\text { Rana } \\
\text { Pratap } \\
\text { Sagar }\end{array}$ & $\begin{array}{l}75.54 \mathrm{E}, \\
24.78 \mathrm{~N} \\
\text { Madhya } \\
\text { Pradesh }\end{array}$ & 170 & $\begin{array}{c}\text { SARAL - } \\
653,840 \\
\text { JASON2 } \\
-105\end{array}$ & $\begin{array}{c}8.5 \mathrm{~km}, \\
4.5 \mathrm{~km} \\
6 \mathrm{~km}\end{array}$ \\
\hline $\begin{array}{c}\text { Ukai } \\
\text { Dam/ } \\
\text { Reservoir }\end{array}$ & $\begin{array}{l}73.64 \mathrm{E}, \\
21.24 \mathrm{~N} \\
\text { Gujarat }\end{array}$ & 612 & $\begin{array}{c}\text { SARAL- } \\
825\end{array}$ & $10 \mathrm{~km}$ \\
\hline
\end{tabular}

\begin{tabular}{|c|c|c|c|c|}
\hline Lake & $\begin{array}{c}\text { Location } \\
\text { (Lon./Lat., } \\
\text { degree) }\end{array}$ & $\begin{array}{c}\text { Area } \\
\text { (sq. } \\
\mathrm{km})\end{array}$ & $\begin{array}{c}\text { Satellite } \\
\text { Track }\end{array}$ & $\begin{array}{c}\text { Width } \\
\text { along the } \\
\text { pass } \\
\text { (Approx.) }\end{array}$ \\
\hline Wular & $\begin{array}{c}74.53 \mathrm{E}, \\
34.36 \mathrm{~N} \\
\mathrm{~J} \& \mathrm{~K}\end{array}$ & $\begin{array}{l}30- \\
260\end{array}$ & $\begin{array}{c}\text { SARAL- } \\
554\end{array}$ & $3 \mathrm{~km}$ \\
\hline Chilka & $\begin{array}{c}85.49 \mathrm{E}, \\
19.77 \mathrm{~N} \\
\text { Orissa }\end{array}$ & 1165 & $\begin{array}{c}\text { SARAL- } \\
137 \\
\text { JASON2 } \\
-192\end{array}$ & $\begin{array}{l}29 \mathrm{~km} \\
24 \mathrm{~km}\end{array}$ \\
\hline Pulicat & $\begin{array}{l}\text { 80.07E, } \\
13.63 \mathrm{~N} \\
\text { Andhra } \\
\text { Pradesh }\end{array}$ & 450 & $\begin{array}{c}\text { SARAL- } \\
410\end{array}$ & $9 \mathrm{~km}$ \\
\hline Sambhar & $\begin{array}{c}75.09 \mathrm{E}, \\
26.92 \mathrm{~N} \\
\text { Rajasthan } \\
\end{array}$ & $\begin{array}{l}190- \\
230\end{array}$ & $\begin{array}{c}\text { SARAL } \\
-653\end{array}$ & $4 \mathrm{~km}$ \\
\hline Upper & $\begin{array}{c}77.31 \mathrm{E}, \\
23.24 \mathrm{~N} \\
\text { Madhya } \\
\text { Pradesh } \\
\end{array}$ & 31 & $\begin{array}{c}\text { SARAL- } \\
210\end{array}$ & $1.5 \mathrm{~km}$ \\
\hline Mansarovar & $\begin{array}{c}81.4 \mathrm{E}, \\
30.69 \mathrm{~N}\end{array}$ & 410 & $\begin{array}{c}\text { SARAL- } \\
582\end{array}$ & $21 \mathrm{~km}$ \\
\hline Rakshatal & $\begin{array}{l}81.29 \mathrm{E}, \\
30.64 \mathrm{~N},\end{array}$ & 284 & $\begin{array}{c}\text { SARAL- } \\
223 \\
\text { JASON2 } \\
-181 \\
\end{array}$ & $\begin{array}{l}11 \mathrm{~km} \\
11 \mathrm{~km}\end{array}$ \\
\hline SonaNadi & $\begin{array}{c}78.71 \mathrm{E}, \\
29.59 \mathrm{~N}, \\
\text { Uttarakhand }\end{array}$ & 64 & $\begin{array}{c}\text { SARAL- } \\
395\end{array}$ & $4 \mathrm{~km}$ \\
\hline NizamSagar & $\begin{array}{l}\text { 77.97E, } \\
18.16 \mathrm{~N} \\
\text { Andhra } \\
\text { Pradesh }\end{array}$ & 43 & $\begin{array}{c}\text { SARAL } \\
109\end{array}$ & $1 \mathrm{~km}$ \\
\hline
\end{tabular}

Table 4. Selected lakes for water level monitoring using satellite radar altimetry over Indian region

Table 3. Selected reservoirs for water level monitoring using satellite radar altimetry over Indian region 